\title{
Hervormde spore op die Tukkie kampus - 'n Kroniek van die tweede 50 jaar
}

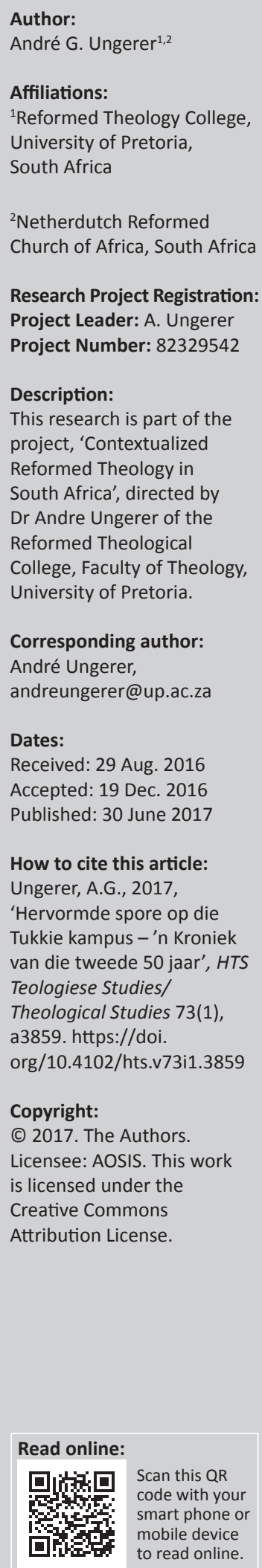

This article is about the 2 nd half (50 years) of the centenary of the Nederduitsch Hervormde Kerk van Afrika (NHKA) at the University of Pretoria (UP). The NHKA was the first church to join the Faculty of Theology at UP in 1917. The previous article 'Hervormde footprints on the Tukkie campus - a chronicle of the first fifty years' contains the humble beginnings, the steady growth, the political background during the apartheid years, and the NHKA's role in justifying apartheid. The 70s and the 80 s was a flourishing time for the Church with a steady growth in membership, an increase in the number of lecturers and students, and more or less enough money to sustain theology education at UP. During the nineties there was a decrease in membership numbers with the pivot point in 1992: from thereon there was a steady decline which was accelerated by the church schism in 2011 and onward. The two Sections of the NHKA and the Nederduitse Gereformeerde Kerk (NGK), Section A and B, became one in 2000. The Reformed Theology College (RTC), with the aim of church specific education for students of the NHKA, was also established in 2000 with prof. T.F.J. Dreyer as the first head. In November 2015 a student protest action \#FeesMustFall rocked the foundation of higher education in South Africa. The issue of language and curriculum as aftermath of the protest actions was also at stake during 2016. During 2017 the centennial celebration of the Faculty of Theology at UP will take place. It coincides with REFO 500 - the commemoration of 500 years of the Reformation.

\section{Inleiding}

Hierdie artikel handel oor die tweede helfte van die Nederduitsch Hervormde Kerk van Afrika (NHKA) se honderdjarige verbintenis met die Universiteit van Pretoria (UP). In die eerste artikel ${ }^{1}$ is daar gehandel oor die aanloop tot die vestiging van die opleiding aan UP, die eerste dosente en studente, leerplanne, en veral oor die verhouding tussen die Fakulteit en die Kerk in die hoogbloei van apartheid.

Die onderhawige bespreking strek van 1970 tot 2017. Die eerste drie dekades handel oor die uitbou van die Fakulteit wat hand aan hand met die hoogbloei van die NHKA geloop het. Sedert die vroeë negentigs het lidmaatgetalle begin taan. Die jaar 2000 is gekenmerk deur ingrypende verandering deurdat die Fakulteit se vorige bedeling met Afdeling A van die NHKA en Afdeling $B$ van die Nederduitse Gereformeerde Kerk (NGK) tot een veelkerklike fakulteit versmelt het. Die Algemene Kerkvergadering (AKV) in 2010 was die aanloop tot ' $n$ kerkskeuring in die NHKA waarvan die voltrekking veral in 2011 begin het. Aan die einde van 2015 het studenteprotes onder die hutsmerk \#FeesMustFall Suid-Afrika geskud en is die transformasie van hoër onderwys met betrekking tot taalbeleid en kurrikulum skielik op die voorgrond geplaas. Gedurende 2017 word die 100ste bestaansjaar van die NHKA aan UP herdenk wat ook met die 500ste bestaansjaar van die Reformasie (1517) saamval.

\section{Evaluering en selfinterpretasie 1971-1980²}

Die Ou Letteregebou word op 03 Augustus 1971 as historiese monument verklaar hoewel teologielesings steeds in die gebou voortgesit is. Op 19 Februarie 1980 neem die Fakulteit kennis dat die klasse na die Nuwe Letteregebou gaan verskuif (Oberholzer 2010:94).

Prof. J.P. Oberholzer is met ingang van 01 Januarie 1971 aangestel as professor in Ou Testament in die plek van prof. E.S. Mulder wat emeritaat aanvaar het (Oberholzer 2010:94). Prof. W.C. van Wyk

1.'Hervormde voetspore op die Tukkie kampus -'n kroniek van die eerste vyftig jaar.' Dit sluit in die aanloop $1909-1916$ en $1917-1970$ Hoewel dit ' $n$ periode van meer as 50 jaar verteenwoordig, is besluit om by die indeling van Oberholzer (2010) te hou.

2.Opskrifte stem ooreen met die opskrifte van prof. dr J.P. Oberholzer (2010) se artikel: Oberholzer, J.P., 2010, 'Evaluering en selfinterpretasie 1971-1980', in 'Honderd Jaar Kerk en Teologiese Opleiding: 'n Kroniek van die Hervormde Kerk', HTS Teologiese Studies/Theological Studies, suppl. 9, 66(3), Art. \#921, 20 pages. DOI: 104102/hts.v66i3.921 
het op 01 Julie 1971 vir prof. Van Selms as hoof van die Departement Semitiese Tale opgevolg (Oberholzer 2010:95).

\section{Politiek en kerklike politiek}

Die politiek van die dag word steeds sterk in die NHKA se doen en late gereflekteer en binnekerklik is daar ook kerkpolitiek wat tot 'n kontroversiële besluit lei. Dit wentel rondom dr A.G.J. Dreyer se benoeming as professor in Nuwe Testamentiese wetenskap. Die vergadering van professore en die Kuratorium het vir Dreyer aanbeveel, maar die Kommissie van die Algemene Kerkvergadering (vervolgens na verwys as Kommissie) wou nie die benoeming bekragtig nie. As rede is aangevoer dat daar nie sekerheid was oor wat die gesindheid van Dreyer sou wees wanneer dit by die hantering van besluite van meerdere vergaderings sou kom nie:

... is die Kommissie nie oortuig dat die gesindheid teenoor en/of die hantering van besluite van meerdere vergaderinge deur die aanbevole kandidaat in alle opsigte (is wat hy) by die professore in die teologiese opleiding sal wil vind nie. (NHKA 1972 soos aangehaal in Oberholzer 2010:95)

Die Kuratorium en die Kommissie het op 22 Maart 1972 'n vergadering gehad en na 'n breedvoerige gesprek is daar met 'n meerderheid van 12 stemme teenoor 10 besluit om dr G.M.M. Pelser vir die pos te benoem. Dit het sterk reaksie by sommige persone uitgelok en die nadraai hiervan het vir lank in die kerklike vergaderings weerklink (Kuratorium 1972 soos aangehaal in Oberholzer 2010:95-96). Professor G.M.M. Pelser het op 1 Julie 1972 diens aanvaar (Oberholzer 2010:96).

Met die 57ste AKV wat op 25 April 1973 'n aanvang geneem het, het die Kommissie verskoning teenoor dr Dreyer met onder andere die volgende woorde aangebied:

Die Kommissie verklaar dat in sy korrespondensie met die Kuratorium woorde gebruik is wat anders opgeneem is as wat die Kommissie daarmee bedoel het ... Dit spyt die Kommissie dat hierdie woorde gebruik is. Die Kommissie gee hiermee te kenne dat dit nie sy bedoeling was om daarmee enige smet op dr Dreyer te lê nie. (NHKA 1973 soos aangehaal in Oberholzer 2010:98)

Tydens dieselfde vergadering is Artikel III herbevestig en was daar sterk ondertone van 'n volkskerkteologie teenwoordig. Daar is besluit om 'n herderlike skrywe met ' $n$ oplaag van 50000 eksemplare in gedrukte vorm te versprei (NHKA 1973 soos aangehaal in Oberholzer 2010:99). Oberholzer (2010) het hieroor soos volg opgemerk:

Dit is vandag moeilik om woorde te vind om die gevoelens weer te gee by die herlees van hierdie herderlike skrywe. Dit is destyds deur die oorgroot meerderheid van ampsdraers en lidmate verwelkom en aangeprys, en dit was inderdaad 'n getroue weergawe van die gedagtes van die oorgroot meerderheid van Hervormers. Juis daarom is dit ' $n$ traumatiese ervaring om weer daarvan kennis te neem. Vandag moet 'n mens immers ernstige vraagtekens stel agter nie alleen bepaalde uitdrukkings nie maar agter die totale selfinterpretasie wat daarin te voorskyn tree en waarvoor op Bybelse sanksie aanspraak gemaak word. (p. 99)

\section{Nuwe dosente en statistieke}

Op 17 September 1973 word ds. A.P.B. Breytenbach deur die vergadering van professore as dosent in Bybelkunde $(\mathrm{Ou}$ Testament) benoem (Oberholzer 2010:99). Die Kommissie het later op 13 Junie 1980 Breytenbach se benoeming as medeprofessor in die departement Ou Testamentiese wetenskap bekragtig (NHKA 1980 soos aangehaal in Oberholzer 2010:112). Op 20 Februarie 1979 het die Fakulteit vir prof. P.J. van der Merwe as prof. F.J. van Zyl se opvolger in die departement Godsdiens- en Sendingwetenskap verwelkom (Oberholzer 2010:110).

Op 12 Augustus 1977 het die Kuratorium die volgende syfers onder oё geneem (Kuratorium 1977 soos aangehaal in Oberholzer 2010:108): van die studente wat inskryf, voltooi slegs ongeveer $24.0 \%$ die studie binne ses jaar, terwyl 'n verdere $12.0 \%$ binne sewe jaar, $6.0 \%$ binne ag jaar, 3.0\% binne nege jaar en 'n verdere $6.0 \%$ na meer as nege jaar afstudeer. Slegs $51.6 \%$ van die ingeskrewe studente voltooi die studie (met die syfers van 1941-1970 as basis). Oor die tydperk 1917-1970 het 517 studente ingeskryf en 272 die studie voltooi (net meer as $50.0 \%$ ).

\section{Vroue in die amp}

Daar word op die 59ste AKV wat op 15 Mei 1979 'n aanvang geneem het, besluit om vroue as dienaars van die Woord toe te laat. Teen daardie tyd was daar drie vroue studente wat met hul studie besig was naamlik, Yolanda Dreyer, Kotie van der Westhuizen en Elsie Wolmarans (NHKA 1997 soos aangehaal in Oberholzer 2010:111). Later sou dr Elsabé Kloppers die eerste vrouepredikant in Suid-Afrika wees wat 'n doktorsgraad in Teologie verwerf het (NHKA 2012:1).

\section{Groei, vooruitskouing, terugskouing 1981-1987}

Hierdie era het ook sy kwota nuwe dosente opgelewer. Op 20 September 1983 besluit die Kuratorium eenparig op die volgende benoemings: dr T.F.J. Dreyer as hoogleraar in Praktiese Teologie in die plek van prof. De Wet wat onverwags oorlede is, dr A.G. van Aarde as mede-professor in Nuwe Testamentiese wetenskap en prof. P.M. Venter in die vakature in Bybelkunde wat ontstaan het (Kuratorium 1983 soos aangehaal in Oberholzer 2010:117). Op 26 September 1986 het die Kommissie die benoemings van dr J.H. Koekemoer as direkteur van die Sentrum vir Voortgesette Teologiese Toerusting (SVTT) en dr G.C. Velthuysen as mede-professor in Dogmatiek en Christelike Etiek goedgekeur (NHKA 1986 soos aangehaal in Oberholzer 2010:125).

\section{Kerk en wêreld 2000}

Die publikasie Kerk en Wêreld 2000 het op die horison gewink. Daar is reeds tydens die Kommissievergadering van 27-28 November 1980 besluit om moontlike skrywers te nader vir 'n publikasie Kerk en Wêreld 2000. Die publikasie se fokus was 'n ondersoek na die werklikhede en moontlikhede van die huidige sosio-ekonomiese situasie in die land. Daar moes 
ook spesifiek na die voorsiene ontwikkeling in die volgende twee dekades gekyk word (NHKA 1980 soos aangehaal in Oberholzer 2010:113). Die publikasie Kerk en Wêreld 2000 het vyf jaar later in 1985 verskyn. Oberholzer (2010) skryf hieroor soos volg:

Dit was slegs nege jaar voor die radikale verandering in die politieke toneel wat met die verkiesing van 1994 sy beslag gekry het. Die publikasie was 'n poging om die oë van ampsdraers en lidmate van die kerk oop te maak vir werklikhede wat tot dan toe te gemaklik verbygesien is. (p. 120)

Die 61ste AKV wat op 12 Mei 1986 'n aanvang geneem het, het ' $n$ strategie aanvaar wat deur die Kommissie voorgelê is na aanleiding van die projek Kerk en Wêreld 2000. Die strategie was onder die hoofde: bevordering van die teologiese arbeid, bevordering van ekumeniese verband, die vryheid en verantwoordelikheid van die kerk op staatkundig politieke gebied, die verantwoordelikheid van die kerk op sosiaaletiese gebied, sowel as die kerklike bediening (NHKA 1986 soos aangehaal in Oberholzer 2010:124).

'n Oorsig van die basiese inhoud van Kerk en Wêreld 2000 word in 'n herderlike skrywe, soos goedgekeur op 19 Junie 1986, die Kerk ingestuur (NHKA 1986 soos aangehaal in Oberholzer 2010:123). Die nadraai was dat die Kommissie op 26 Junie 1987 'n artikel met sterk bewoorde kritiek deur ds. J.H. Breytenbach teenoor Kerk en Wêreld 2000 behandel het. In dié artikel het Breytenbach genoem dat terme soos neoMarxisme, die skeeftrekking van die kerk se belydenis, 'n taal wat vreemd is aan die kerk, die liberale denke, 'n uiters eensydige blik op die toekoms, 'n stuk kibernetiek, humanisme, ensovoorts, Kerk en Wêreld 2000 onaanvaarbaar maak (NHKA 1987 soos aangehaal in Oberholzer 2010:127).

\section{Witfonteinfees en hoogbloei}

Die Witfonteinfees, die honderd jaar sedert die mislukte kerkvereniging, is gedurende die naweek van 14-16 Maart 1986 herdenk. Op Vrydagaand 14 Maart 1986 was daar in die Dirk van der Hoffsaal 'n program getitel Stryd, roeping en voortbestaan. Saterdag se byeenkoms was op die plaas Witfontein, die terrein waar die sinkkerk van die Konsulentsgemeente van Pretoria oorspronklik gestaan het, en wat nog in besit van nasate van die Witfonteinse Prinsloos was. Daar was bykans 2500 mense by hierdie feesgebeure betrokke. 'n Gedenkalbum (1986) het in hierdie tyd verskyn wat die tydperk 1886-1986 uitgebeeld het (Oberholzer 2010:120-121).

Die jare tagtig het die hoogbloei van die Kerk gekenmerk. In 1985 was daar 149 studente waarvan 17 dames was. In dieselfde jaar was daar 130981 belydende lidmate wat deur 261 predikante in gemeentes bedien is. Daarnaas was daar 18 predikante met besondere opdrag, 16 teologiese dosente, 26 dienspligkapelane, 9 deeltydse predikante en 6 predikante met studieverlof (NHKA 1986 soos aangehaal in Oberholzer 2010:122). Oberholzer het 'n onrustigheid oor 'n dalende tendens begin ervaar en op vergaderings begin verwoord. In 'n verslag aan die Kuratorium op 3 September 1986, het hy daarop gewys dat teen 1988 daar ongeveer 14 predikante surplus sou wees (Kuratorium 1986 soos aangehaal in Oberholzer 2010:124).

\section{Rasionalisasie en optimalisering 1988-1997}

Ontwikkelinge op onderwysgebied, dalende lidmaatgetalle en finansiële druk noop die Kerk en Fakulteit, om veral in die negentigs, te begin beplan aan herstrukturering en personeelvermindering. In die middel tagtigs was daar nog genoeg finansiële hulpbronne en kon daar naas die gewone akademiese opleiding aan die Fakulteit ook voorsiening vir voortgesette opleiding vir predikante in die vorm van die SVTT gemaak word.

\section{Die Sentrum vir Voortgesette Teologiese Toerusting}

Die Sentrum vir Voortgesette Teologiese Toerusting (SVTT) vind in hierdie era sy ontstaan net om later ingekort te word om in 'n afgeskaalde vorm voort te bestaan. Die Kommissie van die Algemene Kerkvergadering het op 21 Maart 1986 die reglement vir die SVTT bekragtig waarvan dr J.H. Koekemoer as eerste direkteur benoem is (NHKA 1986 soos aangehaal in Oberholzer 2010:121). Die eerste SVTT vir 1987 het oor die pastoraat vir predikante en Bybelgebruik vir lidmate gehandel. As tweede direkteur van SVTT is dr M.J. du P. Beukes op 02 Augustus 1988 benoem (Oberholzer 2010:130). Op 16 Maart 1989 het die Kommissie van die Algemene Kerkvergadering toestemming verleen dat dr J.A. van Biljon, dr J. Coetzee en dr C.J.A. Simpson spesialishulp verleen in die SVTT (NHKA 1989 soos aangehaal in Oberholzer 2010:131). Prof. L.J.S. Steenkamp is op 01 Januarie 1990 as direkteur van die SVTT aangestel in die plek van prof. Koekemoer wat as hoogleraar en hoof van die Departement Dogmatiek en Christelike Etiek aangestel is (Oberholzer 2010:135).

Op 02 Februarie 1994 word besluit dat die SVTT moet uitfaseer en dat die pos van direkteur SVTT afgeskaf moet word (Kuratorium 1994 soos aangehaal in Oberholzer 2010:147). Op 28-29 April 1994 besluit die dosentevergadering dat die SVTT geherstruktureer word en die naam verander word na die Sentrum vir Teologiese Navorsing en Toerusting (STNT). Prof. L.J.S. Steenkamp is op 21 Julie 1994 benoem om die navorsing in die Fakulteit te koördineer, die administrasie van die Hervormde Teologiese Studies te behartig en die STNT programme in stand te hou (Oberholzer 2010:148). Uiteindelik het die finansiële knyptang die Kerk genoop om die twee poste van die STNT teen Junie 1998 uit te faseer (Oberholzer 2010:165).

\section{Die 75ste bestaan van die Fakulteit}

Die 75ste bestaan van die Fakulteit Teologie is gedurende 1992 op verskillende maniere gevier. Daar is veral in Die Hervormer en die HTS artikels gepubliseer. Die HTS, Jaargang 48, Aflewering 1 en 2 van Maart en Junie 1992 wat aan Prof. dr J.P. Oberholzer opgedra is, het uitstekende 
artikels gedra oor die opleiding aan die Fakulteit asook die teologie wat deur die dosente tot in daardie stadium beoefen is (Oberholzer 2010:143).

Die Fakulteit se jaarverslag van 10 Maart 1992 vermeld dat naas die 11 voltydse dosente (wat SVTT en Bybelkunde insluit), daar ook 22 deeltydse dosente werksaam was. Die volgende dosente is gedurende hierdie era benoem en in diens gestel: die Kuratorium benoem prof. S.J. Botha gedurende 'n buitengewone vergadering op 26 Mei 1992 as hoogleraar in Kerkgeskiedenis (Kuratorium 1992 soos aangehaal in Oberholzer 2010:140). Dr L.C. Bezuidenhout word op 16 Junie 1993 as dosent in Bybelkunde benoem (Kuratorium 1993 soos aangehaal in Oberholzer 2010:146).

Die hoogtepunt wat die totale lidmaattal (doop en belydend) betref, was in 1987 toe dit op 196323 gestaan het. Die hoogste getal belydende lidmate (volwassenes bo die ouderdom van 16-17 jaar wat openbare belydenis van geloof afgelê het) is in 1992 getel met 'n getal van 134160 (Almanak 2016:236). Die predikantetal in 1992 was 332 voltyds en 31 deeltyds in gemeentes, wat 'n gemiddeld van ongeveer 363 belydende lede per predikant gegee het. Daarbenewens was daar 11 dosente, 18 dienspligkapelane, 15 predikante met besondere opdrag, 12 sonder standplaas en 8 wat verder studeer het (NHKA 1992 soos aangehaal in Oberholzer 2010:142).

Sedert 1993 het lidmaattalle 'n geleidelike afwaartse kurwe getoon wat met die kerkskeuring in 2011 verdere momentum gekry het. Die belydende lidmaattal gedurende Augustus 2015 het op 81685 gestaan - dit beteken 'n verlies van 52475 oor die afgelope 23 jaar en 'n gemiddelde verlies van 2282 belydende lidmate per jaar (Almanak 2016:236). Indien die afnemende tendens bly voortduur soos tans, beteken dit dat die Hervormde Kerk teen 2051 geen lidmate meer sal oorhê nie. Ook wat studentegetalle betref is daar ' $n$ afwaartse kurwe. Die laaste groot klasgroep was die 11 sesdejaars wat aan die einde van 2014 gelegitimeer is (NHKA 2014:2-3). Tans is daar 24 studente aan UP wat oor al ses die jaargroepe versprei is. Daar het sewe onderhoude met voornemende studente plaasgevind wat beoog om hulle teologiese studies in 2017 te begin (Kuratorium 2016:2). 'n Mens kan net hoop dat die studentegetalle weer in die toekoms sal vermeerder.

\section{Rasionalisasie en beplanning tot herstrukturering}

In 'n buitengewone vergadering van die Kommissie op 23 Julie 1996 is bespreking gevoer oor die finansiële krisis in die Kerk en is besluit om die personeelstaat met vier poste by die Fakulteit Teologie (Afdeling A) te verminder (NHKA 1996 soos aangehaal in Oberholzer 2010:157). Die eerste gesprekke het begin plaasvind oor die samesmelting van die Fakulteit Teologie se Afdelings A en B. Die Dekanekomitee het op 19 September 1997 onder andere die volgende besluit verwoord: 'Die twee afdelings is bereid om saam te werk'. Die Dekanekomitee het ook 'n Verklaring van Voorneme uitgereik waarvan punt 7 die volgende bewoording oor die samewerking bevat het:
Die omvangryke herstrukturering wat voorsien word, sal 'n billike en realistiese oorgangstyd verg, veral teen die agtergrond van gevestigde belange. 'n Tydskaal wat vir kort, medium- en langtermyndoelwitte voorsiening maak, sal opgestel word. (Oberholzer 2010:163)

Die gebeure rondom herstrukturering het nie ongesiens verbygegaan nie en op die Kommissievergadering van 28 November 1997 is daar deeglik besin oor 'n moontlike eie opleiding en die wenslikheid om aan die universiteit verbonde te bly (NHKA 1997 soos aangehaal in Oberholzer 2010:163). Op 13 Oktober 1998 neem die dosentevergadering 'n brief van die BD III studente ter tafel. Hierdie brief aan die dosente is teen die agtergrond van die onderhandelinge om Afdelings A en B te verenig. Die studente het op 'n deernisvolle wyse hulle steun aan die dosente in hierdie onseker tye toegesê (Oberholzer 2010:168).

\section{Terug by een veelkerklike fakulteit 1998-2009}

Steeds noop die finansiële omstandighede die Kerk om te besnoei en op 30 Julie 1998 word 'n indringende bespreking gevoer oor die bekostiging en infasering van ' $n$ teologiese opleiding met net 6 dosente (Oberholzer 2010:165). Intussen het die Dekanekomitees verskeie vergaderings gehou om die samesmelting van die twee Afdelings te bewerkstellig. Dit het uiteraard tot onsekerheid en spanning gelei - iets wat ook in die notules van die kerklike vergaderings gedurende daardie tyd sigbaar was. Die herstrukturering soos ooreengekom op die Dekanekomitee het onder andere bepaal dat die Fakulteit sal funksioneer as 'n veelkerklike fakulteit, dat 'n kerk op eie koste 'n Kollege kan vestig, dat die postestruktuur sal wees - 6 vir die Nederduitsch Hervormde Kerk, 11 vir die Nederduitse Gereformeerde Kerk en voorlopig 1 vir 'n ander denominasie (Kuratorium 1999 soos aangehaal in Oberholzer 2010).

Op 01 Januarie 2000 het die hergestruktureerde Fakulteit sy werksaamhede begin en die samestelling was soos volg (Oberholzer 2010:173):

- Ou-Testamentiese Wetenskap: A.P.B. Breytenbach (hoof), P.M. Venter, J.H. le Roux, L.C. Bezuidenhout, D. Human.

- Nuwe-Testamentiese Wetenskap: J.G. van der Watt (hoof), S.J. Joubert, A.G. van Aarde, P.A. Geyser, E. Mahlangu.

- Dogmatiek en Christelike Etiek: C.J. Wethmar (hoof), D.E. de Villiers en een vakant (Dr J. Buitendag se benoeming as dosente in Dogmatiek en Christelike Etiek is op 25 Augustus 2000 deur die Kommissie goedgekeur [NHKA 2000 soos aangehaal in Oberholzer 2010:175]).

- Godsdiens- en Sendingwetenskap: P.J. van der Merwe (hoof), J.J. Kritzinger, P.G.J. Meiring.

- Praktiese Teologie: C.J.A. Vos (hoof), J.C. Muller en een vakant.

- Kerkgeskiedenis: J.W. Hofmeyer (hoof).

- Hervormde Teologiese Kollege (HTK): T.F.J. Dreyer (hoof).

- Bestuurder Verrykingsprogramme: P.G.J. Meiring. 
- Bestuurder Navorsingsontwikkeling en -programme: A.G. van Aarde.

- Bestuurder Telematiese onderrig: J.H. le Roux.

Prof. C.J.A. Vos het as dekaan en prof. A.P.B. Breytenbach as adjunk-dekaan gefunksioneer (Oberholzer 2010:173). Op 26 November 2004 is prof. J. Buitendag as adjunk-dekaan aanbeveel en hy was in hierdie pos totdat hy op 1 Maart 2010 as dekaan aangestel is. Prof. D. Human het hom as adjunkdekaan opgevolg (Oberholzer 2010:185).

\section{Die Hervormde Teologiese Kollege}

Die Hervormde Kerk het die geleentheid aangegryp om die Hervormde Teologiese Kollege te vestig wat onder hoofskap van prof. T.F.J. Dreyer op 01 Januarie 2000 sy werksaamhede begin het. 'n Samewerkingsooreenkoms is op 24 November 1999 deur prof. T.F.J. Dreyer namens die Kerk en prof. C.R. de Beer namens die Universiteit, tydens 'n Kuratoriumvergadering onderteken.

Dat die vestiging van die HTK vir die Hervormde Kerk van groot waarde is, is nie te betwyfel nie. Die visie en uitnemende leierskap wat prof. Dreyer in die vestiging en uitbouing van die HTK openbaar het, het tot 'n wenresep gelei. Dit het die NG Kerk gemotiveer om dieselfde model te ondersoek en hulle Kollege is op 01 Januarie 2012 aan UP gevestig. Die HTK het in 2015 sy 15de bestaansjaar gevier. Prof. Dreyer het aan die einde van 2011 emeritaat aanvaar en op 01 Januarie 2012 het dr J.C. van der Merwe as nuwe hoof van die HTK begin. Hierdie pos het hy tot 31 Desember 2014 beklee waarna hy emeritaat aanvaar het. Dr A.G. Ungerer het op 01 Januarie 2015 as nuwe hoof diens aanvaar (Ungerer 2015:2-4).

\section{Nuwe kerklike vennote en kontrakte met die Universiteit van Pretoria}

Twee nuwe kerklike vennote het ook in hierdie tyd by die Fakulteit tuisgekom. Die Uniting Presbyterian Church in Southern Africa (UPCSA) het in 2002 met die Universiteit van Pretoria 'n ooreenkoms gesluit (NHKA 2004 soos aangehaal in Oberholzer 2010:184) en in 2009 het die Uniting Reformed Church of Southern Africa (URCSA) gevolg (Ungerer 2017:30).

Op 24 Junie 2004 word 'n ooreenkoms deur prof. T.F.J. Dreyer en die rektor, prof. C.W.I. Pistorius onderteken. Die ooreenkoms het tot 31 Desember 2009 gestrek (NHKA 2004 soos aangehaal in Oberholzer 2010:181). Op 08 Julie 2009 is 'n volgende ooreenkoms geteken wat vanaf 01 Januarie 2010 sou geld. Daarvolgens sou die Hervormde Kerk vyf professore en die Nederduitse Gereformeerde Kerk tien aan die Fakulteit kon nomineer. Die 30\% bydrae wat elke kerk tot die salarisse van sy dosente maak, is gehandhaaf. Hierdie ooreenkoms kan beëindig word deur enige van die partye met drie jaar kennisgewing, met inagneming van bestaande dosente se diensooreenkomste met die Universiteit (Oberholzer 2010:192).

\section{Colloquium}

Die Kommissie van die Algemene Kerkvergadering het onder leiding van die voorsitter, prof. J. Buitendag 'n colloquium oor strategiese beplanning gedurende 07-09 April 2006 op Hammanskraal gelei. Sowat 120 lidmate en ampsdraers was daarby betrokke. In 'n verklaring van voorneme is gestel dat daar gekyk moet word na maniere waarop die NHKA en die HKSA nader aan mekaar kan beweeg; dat die Hervormde Kerk meer aktief ekumenies moet uitreik na ander kerke; dat die diversiteit van kerke, gemeentes en individue binne die totale kerk van Christus nie ' $n$ bedreiging is nie, maar ook nie toegelaat mag word om die evangeliese eis van eenheid te laat ontspoor nie; en dat die kerk daadwerklik betrokke moet wees daarby om die maatskaplike nood van mense binne en buite die kerk te help verlig (NHKA 2006 soos aangehaal in Oberholzer 2010:187).

Die uitkomste van die colloquium het gemengde reaksie ontlok. Die redakteur van Die Hervormer, dr D.J.C. van Wyk was positief: 'As daar een ding is wat die colloquium hopelik in die kerk wakker gemaak het, is dit entoesiasme. Die tyd vir saam praat is reeds hier...' (Oberholzer 2010:188). Uit 'n ander oord is die vernuwing wat bepleit is met ernstige agterdog bejeen. Oberholzer verwys na berigte wat Die Hervormer gedra het waarvan onderstaande bewoording vanuit die HCM Fourie-Stigting kom:

Die nasionale colloquium ... se grondslag en modus operandi is strydig met ons Bybels-Reformatoriese Teologie en ons kerkordelike bestel. Die uitkomste van die colloquium, soos in die Gesamentlike Verklaring van Voorneme vervat, is vir ons in geheel onaanvaarbaar. (Oberholzer 2010:188)

\section{Nuwe dosente in hierdie era}

Die Kommissie van die Algemene Kerkvergadering het op 02 Desember 2005 in'n buitengewone byeenkoms goedgekeur dat dr E. van Eck aanbeveel word vir die vakante pos in Nuwe Testamentiese Wetenskap (NHKA 2005 soos aangehaal in Oberholzer 2010:187). Dr J.P. Labuschagne se benoeming as dosente in Kerkgeskiedenis word op 05-06 September 2007 deur die Kommissie goedgekeur. Sy aansoek tot opheffing van sy emeritaat is ook goedgekeur. Sy aanstelling sou in 2009 verstryk (NHKA 2007 soos aangehaal in Oberholzer 2010:188). Op 5 November 2009 benoem die Kommissie dr W.A. Dreyer vir die deeltydse termynpos in Kerkgeskiedenis in die plek van dr J.P. Labuschagne (NHKA 2009 soos aangehaal in Oberholzer 2010:193).

\section{Publikasies}

Op 19 Augustus 2008 het die Kuratorium kennis geneem dat prof. J.P. Oberholzer aangewys is as projekleier in verband met die eeufeesvieringe (1909-2009) van die Kuratorium (Kuratorium 2008 soos aangehaal in Oberholzer 2010:191). Die aanvanklike besluit dat dit verkieslik 'n gedenkalbum sou wees, het in 'n supplementum van die HTS met voorwoorde en 10 hoofstukke ontwikkel. Hierdie werk was sedert publikasie in 2010 in groot aanvraag gewees en op 
09 Augustus 2016 was dit reeds 43749 kere afgelaai (kyk http:/ / www.hts.org.za/index.php/HTS/issue/view/39). Dit is merkwaardig dat daar soveel belangstelling is aangesien die NHK'n klein kerk is en die artikels in Afrikaans gepubliseer is. Dit toon dus dat die inhoud vir 'n groot lesersgroep relevant en aktueel is.

In dieselfde jaar waarin die honderdjarige bestaan (2009) van die Kuratorium herdenk is, het die tydskrif, Hervormde Teologiese Studies, nou HTS Teologiese Studies/Theological Studies, 'n aanlyntydskrif geword (kyk http:/ /www.hts.org. za). Die HTS waarvan die NHKA die eienaarskap het, het hoofsaaklik deur die bestuur en dryfkrag van professor A.G. van Aarde, gevestig geraak as 'n wêreldbekende en gerekende teologiese tydskrif met 'n aansienlike getal buitelandse medewerkers. Dit was egter die fakulteitslede, voltyds sowel as deeltyds, wat die meeste gedoen het om gereelde verskyning moontlik te maak. Van hierdie fakulteitslede het artikels gelewer lank voordat hulle tot die Fakulteit toegetree het (Oberholzer 2010:192).

\section{Kerkskeuring, hertoelating tot ekumeniese liggaam en transformasie 2010-2016}

Die aanloop tot die kerkskeuring kom ver en om oor die diepsnydende gebeure in 'n kort bestek te berig, is bykans onmoontlik. Met enkele kwashale word die hoofmomente weergegee.

Die 67ste AKV het besluit dat die NHKA weer lidmaatskap met die Wêreldbond van Hervormde Kerke (WARC) moet opneem (NHKA 2004:586). Hierdie liggaam het die NHKA se lidmaatskap in 1982 gesuspendeer waarna die NHKA as lid bedank het. Die besluit van die WARC in 1982 het uitdruklik drie voorwaardes vir heropname gestel, naamlik:

1. Gelowiges van ander rasse mag nie van Woord- en Tafelgemeenskap uitgesluit word nie.

2. Konkrete barmhartigheid moet aan die slagoffers van Apartheid verleen word.

3. Ondubbelsinnige besluite moet geneem word deur die Algemene Kerkvergadering wat Apartheid verwerp en apartheidstrukture ophef.

Die WARC het bevind dat die NHKA weliswaar aan die eerste twee voorwaardes voldoen het, maar nie toereikend aan die derde nie. Ten spyte van die skuldbelydenis hieroor van die 66ste Algemene Kerkvergadering in 2001 (NHKA 2001:422-423), het die Kommissie besluit om Beskrywingspunt 64 vir die 68ste AKV aan te bied. Met hierdie beskrywingspunt is beoog om die toereikendheid van die Kerk se reeds genome besluite, insluitende die belydenis van 2001, bo alle twyfel te stel. Beskrywingspunt 64 se aanhef, en veral die uiteensetting in 4 punte, het feitlik woordeliks ooreengekom met Besluit 54 wat tydens die 69ste AKV geneem is. Die 68ste AKV het nie die beskrywingspunt aanvaar nie en die saak vir verdere studie verwys. Daar is wel besluit om die voorstel van drr P.B. Boshoff en F.J. Boshoff in ag te neem (NHKA 2007:103-104).
Die Algemene Kerkvergadering verklaar dat dit verkeerd was om 'n bepaalde regeringsbeleid [apartheid] goed te praat. Dit lê nie op die weg van die Algemene Kerkvergadering om politieke beleide goed of af te keur nie. Hierdie erkenning beteken nie dat die Algemene Kerkvergadering die huidige of 'n moontlik toekomstige beleid goedkeur nie. (p. 104)

Gedurende Maart 2009 het vyf dosente van die Hervormde Kerk 'n verklaring oor apartheid in die pers gemaak (NHKA 2010:107). Die verklaring het grootliks met Beskrywingspunt 64 verband gehou en die 69ste Algemene Kerkvergadering (AKV) sou hierdie inhoud weer eens in Beskrywingspunt 54 onder oë neem. Die beskrywingspunt is met ' $n$ meerderheidstem aanvaar en het Besluit 54 geword. Die opskrif was 'Verwerping van Apartheid' en die daaropvolgende inhoud het soos volg gelui:

Die 69ste Algemene Kerkvergadering maak in die lig van die 68ste Algemene Kerkvergadering se besluit dat dit verkeerd was om 'n bepaalde regeringsbeleid (apartheid) goed te praat, onomwonde die uitspraak dat apartheid nie teologies geregverdig kan word nie. Die Kerk verwerp sy goedkeuring van apartheid omdat dit:

- in stryd is met die evangelie van Jesus Christus

- gebaseer is op die idee van onderlinge onversoenlikheid

- onreg sanksioneer

- die beeld van God in mense aantas.

Die vergadering beklemtoon die Bybels-teologiese aard van hierdie verklaring. (NHKA 2010:108-109)

Nadat die besluit geneem is, was daar ' $n$ koor van protes en het 133 bewaardes tougestaan om hul teenstem aan te teken (NHKA 2010:353-356). Na afloop van die vergadering het van die beswaardes met 'n versetbeweging begin. Die druk was aan die oplaai en 'n beswaarskrif is op 22 November 2010 aan die Kommissie oorhandig. Hierdie beswaarskrif het etlike bladsye beslaan en daar is met teologiese redevoering gepoog om Besluit 54 as 'n ultra vires-besluit voor te stel (NHKA 2011:4-11). Daarbý het die beswaardes op 22 Maart 2011 'n persverklaring met 22 onderafdelings uitgereik (SteedsHervormers 2013:8).

Die Kommissie het besluit om 'n Buitengewone Algemene Kerkvergadering (BAKV) vir 4-5 Oktober 2011 te belê (NHKA 2011:10). Tydens die BAKV is die beswaarskrif in elke opsig met'n groot meerderheid afgewys. Die vergadering het bevind dat Besluit 54 van die 69ste AKV nie 'n nuwe leer in die Kerk indra nie. Die vergadering het ook die volgende nuwe besluit geneem en daarmee die Kerk se saak met apartheid afgehandel:

Die Nederduitsch Hervormde Kerk van Afrika verklaar dat die politieke beleid van apartheid wat toegepas is in die Republiek van Suid-Afrika, nie teologies geregverdig kan word nie, en herroep hiermee alle goedkeurings in die verlede van die beleid in uitsprake deur die Kerk en namens die Kerk. Dit was in stryd met die evangelie van Jesus Christus. (NHKA 2011:85)

Tydens 'n vergadering wat plaasgevind het op 12 November 2011 het die beswaardes die volgende besluite geneem: Die steedsHervormers belydenis gespreksgroep word amptelik 
in die lewe geroep. Die steedsHervormers se strydkreet lui soos volg (Steeds Hervormers 2013):

Hierby staan ons, dit kan nie anders nie:

Tree ons weg, tree ons uit die ware LIG.

Tree ons terug, versaak ons die WAARHEID.

Tree ons uit, verloor ons die LEWE. (p. 3)

Gedurende Junie 2012 het die steedsHervormers by/in Meyerspark byeen gekom om 'n Staat van Belydenis (Latyn: Status Confessionis) teen die NHKA te verklaar. Met hierdie Staat van Belydenis - volgens hulle die manier om ten sterkste protes aan te teken - is verklaar dat die evangelie in gedrang is en dat daar sewe ernstige teologiese probleme is waarteen geprotesteer word (SteedsHervormers 2013:16). Hiermee is die NHKA meteens in 'n situasie gestel waar daar tegelyk twee State van Belydenis teen die Kerk bestaan het: die Status Confessionis van die WARC met die Ottawabyeenkoms van Augustus 1982 en die Status Confessionis van die steedsHervormers van Junie 2012 te Pretoria.

Intussen het die steedsHervormers besluit om gemeentes waaroor hulle beheer kon neem, se roerende en onroerende bates aan vrywillige verenigings oor te dra (SteedsHervormers 2013:16). Hierdie gebeure het groot argwaan ontlok en was die rede vir 'n litigasieproses wat begin is ten einde uitsluitsel oor die regmatigheid van hierdie optrede te verkry.

Die stigting van die Geloofsbond van Hervormde Gemeentes (GBHG) tydens die vergadering van die steeds Hervormers in Januarie 2013 het 'n nuwe era ingelui. Gemeentes het die opdrag gekry om te gaan dink en met beskrywingspunte vorendag te kom oor hoe daar by die eerste Bondsvergadering inhoud aan die Bond gegee kon word. Hierdie Bondsvergadering het op 28-30 Julie 2013 by Gemeente Pretoria-Tuine plaasgevind. Daar is besluit om vir eers die Kerkorde van die NHKA te laat geld terwyl 'n komitee aangewys is om 'n nuwe Kerkorde vir die gemeentes wat nou onafhanklik van die NHKA opgetree het, op te stel. Daar is ook besluit om die Staat van Belydenis te handhaaf maar dat die bedoeling nie is om die lidmate van NHKA tot ketters te verklaar nie, maar dat dit eerder as 'n oproep tot gesprek oor die ware leer en lewe van die kerk moet dien (SteedsHervormers 2013:17-18).

Dit spreek vanself dat die kerkskeuring 'n beduidende invloed op die NHKA gehad het. Die letterlik honderde bladsye in agendas en notules van die Kommissie van die AKV en die groot hoeveelheid buitengewone Kommissievergaderings gedurende hierdie tydperk bied insae in die felle stryd wat gewoed het. Die Kommissie het op 13 Junie 2012 'n herderlike skrywe van 12 bladsye, in reaksie op die Staat van Belydenis aan gemeentes uitgestuur, waarin die hele saak in perspektief geplaas is (NHKA 2012). Die Kommissie het deur omsendskrywes en artikels in die kerkliketydskriftemetgemeentes enlidmategekommunikeer. In sommige gemeentes wat nie weggebreek het nie, is daar drukgroepe gevorm wat die saak van die steedsHervormers bevorder het deur skeuring aan te hits. Daar was gesinne en families wat weens die kerkskeuring gepolariseer is met al die gepaardgaande pyn wat dit teweeggebring het (kyk Dreyer 2014:8-10).

Uit die meeste van die wegbreekgemeentes het lidmate na vore gekom wat hulle nie met die motivering en werkswyse van die steedsHervormers kon vereenselwig nie. Hierdie lidmate het meestal onder moeilike omstandighede as gemeente van die NHKA voortbestaan deur elders vir eredienste byeen te kom, die bediening in stand te hou deur nuwe kerkraadslede te verkies, inkomste vir die evangeliebediening te genereer, voortdurende onsekerheid hangende die uitgerekte litigasieproses te trotseer en moedig die regte geloofsperspektief te probeer behou.

Die uitgerekte proses van litigasie ontlok voortdurend by ampsdraers en lidmate vrae en kommentaar wat tekenend is van onsekerheid en frustrasie. Tans is daar wel 'n regter aangewys om die regsproses te bestuur en die saak te verhoor, maar ten tyde van hierdie publikasie is 'n hofdatum steeds nie vasgestel nie.

\section{Hertoelating tot die World Communion of Reformed Churches}

Die World Communion of Reformed Churches (WCRC), wat tot stand gekom het uit die samesmelting van die World Alliance of Reformed Churches (WARC) en die Reformed Ecumenical Council (REC), het in 2007 'n ontmoeting met die NHKA rakende hertoelating tot hierdie ekumeniese liggaam gehad. Beide die NG Kerk en die NHKA se lidmaatskap van die WARC is in 1982 hangende die drie voorwaardes vir hertoelating (waarna reeds verwys is) opgeskort. Tydens hierdie ontmoeting in 2007 is die NHKA daarop gewys dat die afhandeling van punt (3) nog uitstaande is. Sedertdien het die tersaaklike besluite van die 69ste AKV en die BAKV wel aan die vereistes voldoen en is die Kerk se vroeëre teologiese begronding van apartheid ondubbelsinnig herroep. Tydens die 70ste AKV is besluit dat die Kerk aansoek tot herstel van lidmaatskap by die WCRC sal doen. Op 01 Oktober 2013 het die Moderamen 'n gesprek met die afvaardiging van die WCRC gehad waar die eerste amptelike gesprekke om hertoelating plaasgevind het (NHKA 2013:291297). Enkele maande later het die Kommissie op 16 Mei 2014 die Moderamenverslag behandel waarin kennis geneem is dat die NHKA as lid van die WCRC hertoegelaat is. Die Executive Committee of the World Communion of Reformed Churches (WCRC) het kort tevore hierdie besluit te Hannover in Duitsland geneem. Die Maranatha Reformed Church of Christ (MRCC) met wié die NHKA noue historiese bande het, is ook tydens bovermelde geleentheid as lid van die WCRC toegelaat. Hiermee is die Staat van Belydenis van 1982 ook opgehef (NHKA 2014:118-124).

\section{Nuwe dosente}

Ds. T. van Wyk word as dosent-assistent vir prof. J. Buitendag in dogmatiek op 01 Januarie 2010 aangestel. In Januarie 
2016 word sy deeltyds as senior lektor en assistent-redakteur van die HTS aangestel (Van Wyk 2016). Die Kommissie besluit op 11 November 2010 dat die vakante pos in Godsdiens-en Sendingwetenskap deur dr J. Beyers op 01 Januarie 2011 gevul sal word (NHKA 2010:2-3). Dr A.B. Geyser-Fouché is op 01 Augutus 2012 as senior lektor in die departement Ou-Testamentiese Wetenskap aangestel (NHKA 2013:15).

\section{Transformasie}

Op 09 Maart 2015 het 'n Rhodes Must Fall protesbeweging begin. Dit was gemik op die Rhodes-standbeeld wat sedert 1934 by die Universiteit van Kaapstad (UCT) staan. Die kampanje het wêreldwyd aandag getrek en het tot 'n wyer beweging gelei met die doel om SuidAfrikaanse instansies te 'de-koloniseer'. Koloniale en apartheidsverwante standbeelde was in die spervuur en is dwarsoor die land gevandaliseer. Die Raad van UCT het op 09 April 2015 besluit om Rhodes se standbeeld te verwyder (Shay 2016).

Gedurende Oktober 2015 het nog 'n protesoptrede die land onder die vaandel van Fees Must Fall (\#FeesMustFall) geskud. Die protes het by die Universiteit van Witwatersrand begin en na ander universiteite toe oorgespoel. President Zuma het uiteindelik aangekondig dat daar geen verhoging in klasgelde vir 2016 sou wees nie (Zingh 2016).

Vier en tagtig jaar na 1932 toe die voertaal van UP Afrikaans geword het, is Afrikaans as onderrigmedium in gedrang toe daar op Woensdag 22 Junie 2016 besluit is dat Engels voortaan die primêre akademiese taal sal wees. In 'n amptelike dokument wat handel oor die taalbeleid, word onder andere die volgende gestel:

English is the language of teaching and learning (in lecture, tutorials and assessments) except in cases where the object of study is a language other than English, and in programmes with profession-specific language outcomes, subject to approval by Senate. (University of Pretoria 2016:1)

Die nuwe taalbeleid kan vanaf 2017 vir alle nuwe toetreders tot die Universiteit in werking gestel word. Reeds ingeskrewe studente wat só verkies, word toegelaat om hulle studierigtings in Afrikaans te voltooi. Wat die Fakulteit Teologie betref is die voorgestelde beplanning dat nuwe studente vanaf 2017 hul vierjarige BDiv graad in Engels sal deurloop. Die nagraadse, kerkspesifieke MDiv graad asook die Nagraadse Diploma in Teologie en kerklike bediening (NG Dip), sal in Afrikaans deurloop word. Reeds ingeskrewe studente kan hulle studierigting in Afrikaans voltooi (Faculty of Theology 2016:1-2).

'n Wending in hierdie sage het gekom toe die minister van hoër onderwys en opleiding onderneem het om nie voort te gaan met die wysigings aan die universiteit se institusionele statuut voordat die hofsaak tussen UP en die AfriForum oor die taalkwessie afgehandel is nie. AfriForum en Solidariteit het in Julie 2016 ' $n$ aansoek by die hof ingedien dat die besluit oor Engels as voertaal hersien word. Hulle voer aan dat die instelling van 'n nuwe taalbeleid ongrondwetlik is ingevolge artikel 29(9) van die Grondwet. Dit bring mee dat voornemende studente aan UP waarskynlik steeds kan registreer om in 2017 in Afrikaans te studeer (Swanepoel 2016).

Die Kuratorium het in aanloop tot die 71ste AKV'n ondersoek na ander moontlike vorme van teologiese opleiding laat doen. Nadat verskillende moontlikhede ondersoek is, is bevind dat die teologiese opleiding aan die Fakulteit Teologie by UP, tans steeds die beste opsie is. Hierdie verslag dien tydens die 71ste AKV en die Kerk moet in die lig van die huidige omstandighede oor die pad vorentoe besin (NHKA 2016:749-752).

\section{REFO 500 en die 100-jarige feesvieringe -2017}

In die jaar 2017 vind twee merkwaardige herdenkings plaas. Dit sal op 31 Oktober 1517 presies 500 jaar gelede wees dat Martin Luther sy 95 stellings teen die kerkdeur in Wittenberg, Duitsland vasgespyker het. Die NHKA beplan om hierdie gebeure in samewerking met ander kerke op luisterryke wyse te vier. Uiteraard gaan hierdie vieringe ook in die Fakulteit met spesiale lesings en publikasies neerslag vind. Dan is dit ook merkwaardig dat die 100-jarige viering van die Fakulteit Teologie aan UP gelyklopend met REFO 500 plaasvind. Die Fakulteit beplan verskeie geleenthede om hierdie historiese mylpale te gedenk.

Op 06 Maart 2017 vind die 'Oopmaak van die hekke' saam met ' $n$ akademiese wydingsdiens in die Musaion plaas. Dit is pragtige houthekke wat voorheen in Roperstraat toegang tot die universiteit verleen het, uit 'n stoorplek opgediep is, en by aantrede tot die Teologiegebou opgerig gaan word. Die hekke gaan in 'n oop-posisie monteer word. Die verlede word hierdeur vergestalt asook die uitreik na die toekoms. Die vasgemonteerde hekke wil verseker dat geskikte kandidate toegang tot die toekoms sal hê en dat niemand dié voorreg ooit weer ontneem sal word nie. Onderstaande embleme in Afrikaans en Engels (sien Figuur 1) word tans op briefhoofde, baniere en as gedenkplaat aangebring ter herdenking van hierdie belangrike gebeure (Theology Centenary 2016:1).

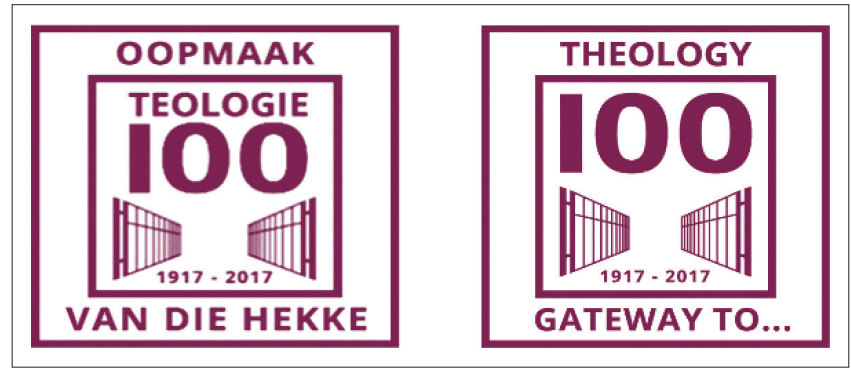

FIGUUR 1: Bostaande embleme in Afrikaans en Engels word tans op briefhoofde baniere en as gedenkplaat aangebring ter herdenking van hierdie belangrike gebeure (Theology Centenary 2016:1). 


\section{Ten slotte}

Sedert die eerste twee Hervormde studente in 1917 by die Fakulteit Teologie ingeskryf het, het 'n magdom gebeure plaasgevind wat onmoontlik volledig weergegee kan word. Die belangrikste gebeure kon aan die hand van die weergawes in notules weergegee word. Dit was dag en datumgebeure wat feitelik en noukeurig neergepen is. Oor die emosies wat met al die gebeure gepaard gegaan het, kan 'n mens maar net raai: dinge soos die onsekerheid aan die beginjare, die lief en leed van studentwees, die ure in lesinglokale, die vorming van elkeen se menswees en karakter, die vele liefdesverhoudings wat aangeknoop is, die dosente se unieke bydraes, konflik en stryd wat met tye gewoed het en vele meer. Die Universiteit van Pretoria en in besonder die Fakulteit Teologie was die middelpunt waarom vele aktiwiteite gewentel het. Dosente kon hulle roeping vervul. Studente is voorberei vir hul bediening in die Kerk. Gemeentes het die produk van die Kerk se opleiding aan UP beleef - meestal met groot tevredenheid - soms met teleurstelling.

Die Hervormde Kerk het 'n kleurryke geskiedenis aan die Universiteit van Pretoria en ons voetspore op die Tukkie kampus lê diep. Dit is met groot dankbaarheid teenoor God dat ons as Kerk hierdie geskiedenis kan herdenk. Soli Deo Gloria!

\section{Erkenning Mededingende belange}

Die outeurs verklaar dat hulle geen finansiële of persoonlike verbintenis met enige party wat hom nadelig of voordelig kon beïnvloed het in die skryf van hierdie artikel nie.

\section{Literatuurverwysings}

2017 Gedenkalbum Nederduitsch Hervormde Kerk van Afrika, 2016, Sentik, Pretoria. Almanak, 2016, Jaarboek van die Nederduitsch Hervormde Kerk van Afrika, Jaargang 110, Sentik, Pretoria.

Dreyer, W.A., 2014, 'Wanneer een twee word: 'n Perspektief op resente gebeure in die Nederduitsch Hervormde Kerk van Afrika', HTS Teologiese Studies/Theological Studies 70(1), Art. \#2054, 16 pages. https://doi.org/10.4102/hts.v70i1.2054

Faculty of Theology, 2016, Language plan of the Faculty of Theology, 20/07/2106, pp. 1-2, unpublished document.

Gedenkalbum, 1986, Gedenkalbum 1886-1986 van die Nederduitsch Hervormde Kerk van Afrika in woord en beeld, NHW Pers, Pretora.

Hervormde Teologiese Studies, 2010, Supplementum 9 - Honderd Jaar Kerk en Teologiese Opleiding: 'n Kroniek van die Hervormde Kerk, besigtig op 09 Aug. 2016, vanaf http://www.hts.org.za/index.php/HTS/issue/view/39

Hervormde Teologiese Studies, http://www.hts.org.za

Kuratorium, 1972, Handelinge van die Kuratorium, 22/03/1972, NHKA Argiewe, Pretoria. Kuratorium, 1977, Handelinge van die Kuratorium, 12/08/1977, NHKA Argiewe, Pretoria. Kuratorium, 1983, Handelinge van die Kuratorium, 20/09/1983, NHKA Argiewe, Pretoria. Kuratorium, 1992, Handelinge van die Kuratorium, 26/05/1992, NHKA Argiewe, Pretoria. Kuratorium, 1993, Handelinge van die Kuratorium, 16/06/1993, NHKA Argiewe, Pretoria. Kuratorium, 1994, Handelinge van die Kuratorium, 02/02/1994, NHKA Argiewe, Pretoria. Kuratorium, 1999, Handelinge van die Kuratorium, 23/03/1999, NHKA Argiewe, Pretoria. Kuratorium, 1999, Handelinge van die Kuratorium, 24/11/1999, NHKA Argiewe, Pretoria. Kuratorium, 2008, Handelinge van die Kuratorium, 19/08/2008, NHKA Argiewe, Pretoria. Kuratorium 2016, Handelinge van die Kuratorium, 16/08/2016, NHKA Argiewe, Pretoria. Nederduitsch Hervormde Kerk van Afrika, 2012, Kort Kerkgeskiedenis, amptelike webblad van die NHKA, besigtig op 24 Aug. 2016, vanaf http://www.nhka.org/ index.php/wie-is-ons-11/kort-geskiedenis.html
NHKA, 1972, Handelinge van die Kommissie van die Algemene Kerkvergadering, 22/03/1972, NHKA Argiewe, Pretoria.

NHKA, 1979, Handelinge van die Algemene Kerkvergadering, 15/05/1979, NHKA Argiewe, Pretoria.

NHKA, 1980, Handelinge van die Kommissie van die Algemene Kerkvergadering, 13/06/1980, NHKA Argiewe, Pretoria.

NHKA, 1980, Handelinge van die gewone vergadering van die Kommissie van die Algemene Kerkvergadering, 27-28/11/1980, NHKA Argiewe, Pretoria.

NHKA, 1986, Handelinge van die Algemene Kerkvergadering, 21/03/1986, NHKA Argiewe, Pretoria.

NHKA, 1986, Handelinge van die Algemene Kerkvergadering, 12/05/1986, NHKA Argiewe, Pretoria.

NHKA, 1986, Handelinge van die Kommissie van die Algemene Kerkvergadering, 26/09/1986, NHKA Argiewe, Pretoria.

NHKA, 1987, Handelinge van die Kommissie van die Algemene Kerkvergadering, 26/06/1987, NHKA Argiewe, Pretoria.

NHKA, 1992, Handelinge van die Algemene Kerkvergadering, 28/06/1992, NHKA Argiewe, Pretoria.

inge van die Kommissie van die Algemene Kerkvergadering, 28/11/1997, NHKA Argiewe, Pretoria.

NHKA, 2001, Handelinge van die Algemene Kerkvergadering, 30/09/2001, pp. 422 423, NHKA Argiewe, Pretoria.

NHKA, 2004, Handelinge van die Kommissie van die Algemene Kerkvergadering, 10-11/06/2004, NHKA Argiewe, Pretoria.

NHKA, 2004, Handelinge van die Algemene Kerkvergadering, 26/09/2004, p. 586, NHKA Argiewe, Pretoria.

NHKA, 2005, Handelinge van die Kommissie van die Algemene Kerkvergadering, 05/11/2005 en 01/12/2005, NHKA Argiewe, Pretoria.

NHKA, 2006, Handelinge van die Kommissie van die Algemene Kerkvergadering, 07-09/04/2006, NHKA Argiewe, Pretoria.

NHKA, 2007, Besluitebundel van die 68ste Algemene Kerkvergadering, 23/09/2007, pp. 103-104, NHKA Argiewe, Pretoria.

NHKA, 2010, Besluitebundel van die 69ste Algemene Kerkvergadering, 26/09/2010, pp. 107-109, NHKA Argiewe, Pretoria.

NHKA, 2010, Handelinge van die 69ste Algemene Kerkvergadering, 26/09/2010, pp. 353-358, NHKA Argiewe, Pretoria.

NHKA, 2010, Handelinge van die Kommissie van die Algemene Kerkvergadering, 10/11/2016, pp. 2-3, NHKA Argiewe, Pretoria.

NHKA, 2011, Handelinge van die Kommissie van die Algemene Kerkvergadering, 18/04/2011, pp. 4-11, NHKA Argiewe, Pretoria.

NHKA, 2011, Handelinge van die Kommissie van die Algemene Kerkvergadering, 18/04/2011, pp.10, NHKA Argiewe, Pretoria.

NHKA, 2011, Handelinge van die Buitengewone Algemene Kerkvergadering, 4-5/10/2011, p. 85, NHKA Argiewe, Pretoria.

NHKA, 2012, Handelinge van die Kommisse van die Algemene Kerkvergadering, Verklaring van die Kommissie van die Algemene Kerkvergadering, Omsendskrywe 10/12, besigtig op 26 Aug. 2016, vanaf http://www.nhka.org/index.php/so-seons-11/omsendbriewe.htm

NHKA, 2013, Handelinge van die Kommissie van die Algemene Kerkvergadering, 07/11/2013, pp. 291-297, NHKA Argiewe, Pretoria.

NHKA, 2013, Handelinge van die Algemene Kerkvergadering, 20/09/2013, p. 50, NHKA, Argiewe, Pretoria.

NHKA, 2014, Handelinge van die Kommissie van die Algemene Kerkvergadering, 05/06/2014, pp.118-124, NHKA Argiewe, Pretoria.

NHKA, 2014, Handelinge van die Kommissie van die Algemene Kerkvergadering, 04/12/2014, pp. 2-3, NHKA Argiewe, Pretoria.

NHKA, 2016, Handelinge van die Algemene Kerkvergadering, 02/10/2016, Bylae $Y$, pp. 749-752, NHKA Argiewe, Pretoria.

Oberholzer, J.P., 2010, 'Evaluering en selfinterptetasie 1971-1980', in 'Honderd Jaar Kerk en Teologiese Opleiding: 'n Kroniek van die Hervormde Kerk', HTS Teologiese Studies/Theological Studies, suppl. 9, 66(3), Art. \#921, 20 pages. https://doi. Studies/Theological Studies,
org/10.4102/hts.v66i3.921

Oberholzer, J.P., 2010, 'Groei, vooruitskouing, terugskouing 1981-1987', in 'Honderd Jaar Kerk en Teologiese Opleiding: 'n Kroniek van die Hervormde Kerk', HTS Teologiese Studies/Theological Studies, suppl. 9, 66(3), Art. \#935, 15 pages. https://doi.org/10.4102/hts.v66i3.935

Oberholzer, J.P., 2010, 'Rasionalisasie en Optimalisering 1988-1997', in 'Honderd Jaar Kerk en Teologiese Opleiding: 'n Kroniek van die Hervormde Kerk', HTS Teologiese Studies/Theological Studies, suppl. 9, 66(3), Art. \#934, 35 pages. https://doi. Studies/Theological Studies,
org/10.4102/hts.v66i3.934

Oberholzer, J.P., 2010, 'Terug by een ekumeniese fakulteit 1998-2009', in 'Honderd Jaar Kerk en Teologiese Opleiding: 'n Kroniek van die Hervormde Kerk', HTS Teologiese Studies/Theological Studies, suppl. 9, 66(3), Art. \#110, 31 pages. Teologiese Studies/Theological Studies,
https://doi.org/10.4102/hts.v66i3.110

Shay, S., 2016, Urgent strategy needed to decolonise university curricula Mail\&Guardian, besigtig op 16 June 2016, vanaf http://mg co.za/article/2016-06 Mail\&Guardian, besigtig op 16 June 2016, vanaf http://mg.co.za/article/2016-06luxury-but-a-necessity 
Singh, K., 2016, \#FeesMustFall campaign back, Mail\&Guardian, http://www.news24. com/SouthAfrica/News/feesmustfall-campaign-back-20160110,10/01/2016, besoek op 08/08/2106

SteedsHervormers, 2013, Inligtingstuk, http://www.steedshervormers.co.za/ verklaring/inligtingstuk-2013, besoek op 06/08/2016

Swanepoel, E., 2016, Hof sal sê oor wettigheid van UP-taalbeleid, Netwerk 24.com, http://www.netwerk24.com/Nuus/Onderwys/hof-sal-se-oor-wettigheid-van-uptaalbeleid-20160806, 07/08/2016, besoek op 08/08/2016

Theology Centenary, 2016, Style Guidelines for Centenary Badge, July 2016, Official Document of the Faculty of Theology, p. 1.
Ungerer, A.G., 2015, HTK Bylaag, Konteks, Oktober 2015, Jaargang 26 No. 09, pp. 2-4, SENTIK, Pretoria.

Ungerer, A.G., 2016, Gedenkalbum van die Nederduitsch Hervormde Kerk van Afrika, p. 30, SENTIK, Pretoria.

Universiteit van Pretoria, 2016, Geskiedenis van die Universiteit van Pretoria, http:// www.up.ac.za/af/about-up/article/258117/history-of-the-university-of-pretoria,
besoek op 08/08/2016

University of Pretoria, 2016, Language policy, Document number: R31/16, approved by Senate as $54631 / 16$ on 22/06/2016 and by the Executive on 21/06/2016 as Rt266/16, pp. 1-3.

Van Wyk, T., 2016, E-pos korrespondensie met dr T. van Wyk op 27 Julie 2016. 